ISSN: 2162-3104 Print/ ISSN: 2166-3750 Online

Volume 8, Issue 2 (2018), pp. 1059-1078

(C) Journal of International Students

http://jistudents.org/

doi: 10.5281/zenodo. 1250408

\title{
Immigration Gridlock: Assessing Whether Canada's Express Entry is an Effective Immigration System for International Students' Transition into Permanent Residency?
}

\author{
Chen Wang \\ University of Ottawa, Canada
}

\begin{abstract}
This research critically analyzes the introduction of the Express Entry system in Canada, requiring foreign nationals to submit an Expression of Interest (EOI) and wait for an invitation before being allowed to apply for permanent residence. Drawing on available empirical data, I argue that this reform jeopardized international students' chance to become permanent residents. Despite recent modifications that intended to improve their situation, the pathways to permanent residence of international students are still restricted. Particularly, international PhD students are negatively impacted as the previously existing PhD stream under the Federal Skilled Worker Program covertly disappeared from the current regime. This research concludes with suggestions on how to further modify the current immigration system to facilitate international students' transitions into Canada.
\end{abstract}

Keywords: Express Entry, Expression of Interest (EOI), Immigration and Refugee Protection Act (IRPA), Immigration and Refugee Protection Regulations (IRPR), international students, permanent residency

In December 2013, Bill C-4, A second act to implement certain provisions of the budget tabled in Parliament on March 21, 2013 and other measures, 
received Royal Assent (Parliament of Canada, 2013). This legal reform symbolized Canada's movement toward an Expression of Interest (EOI) system, which meant the Canadian government could take the initiative to select the highest qualified candidates. Following the practice of New Zealand and Australia, where the EOI system had been successfully implemented for a significant number of years, Canada introduced its own national EOI system under the name of Express Entry. In January 2015, Citizenship and Immigration Canada (CIC) formally launched the Express Entry system for the purpose of managing economic class immigration applications more effectively. By bringing the EOI model to the Immigration and Refugee Protection Act (IRPA), Canada switched from a passive method of processing immigration applications, to a new prioritized system that selected only the most qualified and in-demand individuals. The newly designed Comprehensive Ranking System (CRS) also substantially changed the rules for assessing applicants: first, the CRS requires a supplementary assessment method for applicants to be evaluated in addition to the previous immigration criteria; second, applicants now need to compete with each other in the Express Entry pool based on the points awarded for human capital factors under the CRS.

The effects of this legal reform on international students' ability to secure permanent residence in Canada have been controversial since it came into force. Feedback on the implementation of the Express Entry system from international students triggered different opinions of this immigration regime among Canadian political parties. The previous Conservative government of Canada contended that changes would welcome increasing numbers of immigrants who studied in Canada by processing their applications quicker than previously viable. However, concerns have been raised that international students have a lesser chance of qualifying for permanent residence in Canada after the reforms. Noting the impacts of this amendment on immigration law, and considering the importance of retaining international students as permanent residents, Canada's current Liberal government re-examined the Express Entry system so as to allow more opportunities for qualified international students to remain in Canada. Following an extensive examination, new Ministerial Instructions respecting changes in the points awarding method under the CRS were published in the government of Canada's official Gazette and finally came into force on November 19, 2016. So far, the profound effects of the most recent reforms 
on international students' ability to secure permanent residence in Canada have yet to be established.

This research finds that, at first glance, the chances for international students to receive permanent residency appear to have been improved. However, these students still cannot restore the advantages that they had prior to the implementation of Express Entry. Moreover, international $\mathrm{PhD}$ students are left at a greater disadvantage compared to other international students, as their demands are still ignored or set back by the current immigration laws and policies.

On this account, the purpose of this research is to uncover the specific obstacles facing international students in their transition into permanent residency under Canada's Express Entry system, and to recommend legal reforms and policy changes that would remove these barriers. Specifically, this research argues that Express Entry is neither an effective system for retaining qualified skilled international students inside Canada, nor for facilitating their transition into permanent residency. The paper concludes by offering suggestions on further modifications to the Express Entry system that have not been addressed by the current bill.

\section{LITERATURE REVIEW}

In order to argue for the elimination of the barriers that impede international students' transition into permanent residents, we must address this question as a premise: why is it necessary to attract and retain international students? Numerous scholarly researchers have responded to this question by arguing that international students as a group are the most desirable source of skilled immigrants for receiving countries which stand to benefit from recruiting international students (Beine, Noël, \& Ragot, 2014; Gribble, 2008; King \& Raghuram, 2013; Ziguras \& Law, 2006). The key factors identified include, but are not limited to, their valuable skills, high language proficiency, recognized credentials, country-specific experience, and social connections (Arthur \& Flynn, 2011). These factors greatly contribute to both the smooth integration of international students into the receiving society and their exceptional performance in the labor market. Receiving countries therefore benefit reciprocally from retaining international students, who have already partially integrated into the hosting societies, and consequently they can ensure a highly skilled workforce stock (Raghuram, 2013). 
Aside from international students' potential economic contribution in the long run, studies also reveal that receiving countries have already benefited significantly from international students' expenditures in past years. In many traditional destination countries, the financial contributions from international students are very substantial, as they are liable for considerably higher tuition fees than domestic students (Lange, 2013). In a more specific Canadian context, international students pay 3.4 times more on average for undergraduate programs and 2.3 times more for graduate programs (Hassanein, 2014). International tuition is a major contributor to university funding, and this contribution enables domestic tuition to be kept reasonably low (Bauder, 2014). Canada not only derives benefits from international students' annual expenditures, including tuition and living costs, but also from the government revenue generated by filling vacancies in the labor market (Canadian Bureau for International Education, 2016).

Given all of these benefits, numerous countries attempt to tailor their immigration laws and policies to facilitate student migration (Guellec \& Cervantes, 2001). Canada has been actively making efforts to implement laws and policies geared toward attracting and retaining international students permanently after graduation (She \& Wotherspoon, 2013). These strategies have been proven to be very influential in helping receiving countries develop a more prominent profile across the world as an attractive destination (Beine, Noël, \& Ragot, 2014). On the other hand, studying abroad also can be a deliberate immigration strategy from the perspective of international students (Tremblay, 2005). Due to this reason, evaluating the impacts of current immigration laws on international students is of significant value in facilitating international students' transition, so as to retain potential skilled labor for receiving countries.

Previous research on traditional leading destination countries, such as the UK, the US, Canada, Australia, and New Zealand, has highlighted the highly influential ideologies on attracting and retaining international students worldwide (Bedford \& Spoonley, 2014; Facchini \& Lodigiani, 2014; Findlay, 2010; Gopal, 2016; Hawthorne, 2010). Admittedly, international students' pathways to permanent status are sometimes restricted in certain countries. This is both to protect the jobs of local workers, and to prevent the immigration scheme from being used as a backdoor for entry to settle (Birrell \& Perry, 2009; Dobson \& Salt, 2009; Lee \& Rice, 2007). However, there is extensive literature showing that Canada has generally demonstrated a strong passion for expanding their 
share of the international education market, as well as maintaining a highly skilled immigration stock (Johnstone \& Lee, 2014).

As the EOI system has been previously used in other traditional immigrant receiving countries, such as New Zealand and Australia, existing research also addresses the strengths and weaknesses of this model in similar jurisdictions (Belford \& Spoonley, 2014; Cully, Lim, Smith, \& Levantis, 2011). Studies suggest that this migrant-driven system used in Canada, Australia, and New Zealand is generally more effective than the employer-driven ones in increasing the skill level of the immigrant population (Facchini \& Lodigiani, 2014). In specific reference to the Canadian context, the social effects of implementing these immigration laws and policies have been preliminarily analyzed by critics (Crowley, 2014; Keung, 2015). However, substantial barriers created by the biased laws have not been fully revealed.

Although the aforementioned literature has provided solid grounds for future research to build upon, an examination of the social effects of each reform to the Express Entry system is still insufficient. This research provides an up-to-date response to the policy changes and probes into the practical impacts of these reforms.

\section{RESEARCH METHOD}

This empirical research mainly adopts a quantitative approach by examining official data released by the Canadian government regarding the Express Entry system, and particularly focuses on identifying and analyzing the minimum CRS points that prospective immigrants need in order to qualify for a permanent residency application. By summarizing fluctuating trends of the cut-off point of each draw and highlighting the inflection point, this research provides insight into the underlying obstacles for international students to qualify for permanent residency.

As the new Ministerial Instructions came into force since November 19, 2016, the points distribution for pre-arranged employment and human capital factors under the CRS markedly changed. Therefore, analyses based on the empirical data should be divided into two stages accordingly. The first stage consists of all the draws made before November 19, 2016, while the second stage is comprised of the draws that came afterward. Due to the substantial changes in the CRS points distribution, different implications 
could be interpreted even with the same cut-off points. Therefore, this research will proceed from two stages respectively.

\section{Data Analysis}

Compared to the fixed points-based criteria prior to the introduction of Express Entry, the flexible CRS criteria substantially changed Canada's skilled immigrants selection system by adding additional requirements for immigration candidates before they are invited to apply for permanent residency. On top of meeting the basic points requirements of certain immigration programs, only the highest ranked candidates with a CRS points total above the cut-off score in each draw will receive an Invitation to Apply (ITA).

The CRS awards a full score of 1,200 points to immigration candidates based on their human capital factors and other criteria. Candidates are evaluated on the basis of their skills, work experience, language ability, educational experience, and other factors, which play important roles in economic success for immigrants. Apart from these human capital factors that earn points for candidates, it is particularly worth noting that attaining a provincial nomination or arranged employment supported by a positive Labor Market Impact Assessment (LMIA) brings candidates 600 points. A provincial nomination indicates that a provincial or territorial government recognizes the candidates' potential to contribute to the regional economy. As for the LMIA, it is designed to guarantee that Canadians are put first in line for available jobs. A positive LMIA shows that there is a need for a foreign worker to fill the job and that no Canadian worker is available to do it. With the 600 points from either a provincial nomination or arranged employment with an LMIA, candidates are effectively guaranteed an invitation to apply for permanent residency.

Recently, there were two notable modifications made that are worth highlighting: the decrease in the points awarded for arranged employment from 600 to $50-200$, and the increase in points for Canadian educational credentials to 15 or 30 . The purpose of making these modifications is to balance the points distribution in the CRS.

\section{The First Stage}

The first stage covers the time period from January 2015 to November 19 ，2016. The minimum CRS points needed to be invited during this stage are listed in the Table 1 below : 
Table 1. The Cut-off Score and Number of Invitations to Apply (ITAs) Issued in Canada's Express Entry Draw (January 2015 - November 19, 2016)

\begin{tabular}{|c|c|c|c|c|c|c|c|}
\hline Draw \# & Date & $\begin{array}{l}\text { Cut- } \\
\text { off } \\
\text { Score }\end{array}$ & $\begin{array}{c}\text { Number of } \\
\text { ITAs } \\
\text { Issued }\end{array}$ & $\begin{array}{c}\text { Draw } \\
\#\end{array}$ & Date & $\begin{array}{l}\text { Cut-off } \\
\text { Score }\end{array}$ & $\begin{array}{c}\text { Number of } \\
\text { ITAs } \\
\text { Issued }\end{array}$ \\
\hline 1 & $01 / 31 / 15$ & 886 & 779 & 25 & $01 / 13 / 16$ & 453 & 1518 \\
\hline 2 & $02 / 07 / 15$ & 818 & 779 & 26 & $01 / 27 / 16$ & 457 & 1468 \\
\hline 3 & $02 / 20 / 15$ & 808 & 849 & 27 & $02 / 10 / 16$ & 459 & 1505 \\
\hline 4 & $02 / 27 / 15$ & 735 & 1187 & 28 & $02 / 24 / 16$ & 453 & 1484 \\
\hline 5 & $03 / 20 / 15$ & 481 & 1620 & 29 & $03 / 09 / 16$ & 473 & 1013 \\
\hline 6 & $03 / 27 / 15$ & 453 & 1637 & 30 & $03 / 23 / 16$ & 470 & 1014 \\
\hline 7 & $04 / 10 / 15$ & 469 & 925 & 31 & $04 / 06 / 16$ & 470 & 954 \\
\hline 8 & $04 / 17 / 15$ & 453 & 715 & 32 & $04 / 20 / 16$ & 468 & 1018 \\
\hline 9 & $05 / 22 / 15$ & 755 & 1361 & 33 & $05 / 06 / 16$ & 534 & 799 \\
\hline 10 & $06 / 12 / 15$ & 482 & 1501 & 34 & $05 / 18 / 16$ & 484 & 763 \\
\hline 11 & $06 / 26 / 15$ & 469 & 1575 & 35 & $06 / 01 / 16$ & 483 & 762 \\
\hline 12 & $07 / 10 / 15$ & 463 & 1516 & 36 & $06 / 15 / 16$ & 488 & 752 \\
\hline 13 & $07 / 17 / 15$ & 451 & 1581 & 37 & $06 / 29 / 16$ & 482 & 773 \\
\hline 14 & $08 / 07 / 15$ & 471 & 1402 & 38 & $07 / 13 / 16$ & 482 & 747 \\
\hline 15 & $08 / 21 / 15$ & 456 & 1523 & 39 & $07 / 27 / 16$ & 488 & 755 \\
\hline 16 & $09 / 08 / 15$ & 459 & 1517 & 40 & $08 / 10 / 16$ & 490 & 754 \\
\hline 17 & $09 / 18 / 15$ & 450 & 1545 & 41 & $08 / 24 / 16$ & 538 & 750 \\
\hline 18 & $10 / 02 / 15$ & 450 & 1530 & 42 & $09 / 07 / 16$ & 491 & 1000 \\
\hline 19 & $10 / 23 / 15$ & 489 & 1502 & 43 & $09 / 21 / 16$ & 483 & 1288 \\
\hline 20 & $11 / 13 / 15$ & 484 & 1506 & 44 & $10 / 12 / 16$ & 484 & 1518 \\
\hline 21 & $11 / 27 / 15$ & 472 & 1559 & 45 & $10 / 19 / 16$ & 475 & 1804 \\
\hline 22 & $12 / 04 / 15$ & 461 & 1451 & 46 & $11 / 02 / 16$ & 472 & 2080 \\
\hline 23 & $12 / 18 / 15$ & 460 & 1503 & 47 & $11 / 16 / 16$ & 470 & 2427 \\
\hline 24 & $01 / 06 / 16$ & 461 & 1463 & & & & \\
\hline
\end{tabular}

Note. Adapted from " Express Entry invitation rounds," by Government of Canada, 2017 (http://www.cic.gc.ca/english/express-entry/rounds.asp). In the public domain.

The data above indicates that prospective immigrants in the first four draws and a later draw on May 22, 2015 needed to accumulate more than 700 points to receive an ITA for permanent residency. For international students to transition into permanent residents on these occasions, they most likely had to succeed in obtaining a job offer with an LMIA or a provincial nomination. Acquiring either of these qualifications would have given them 
600 points toward the CRS score. It is rare for an international student to achieve more than 700 points by purely relying on the human capital factors. This also means that international students with a valid job offer or a provincial nomination were likely able to acquire permanent resident status faster than those without these items under the Express Entry system. This disproportionate distribution of points benefited certain candidates with a provincial nomination or arranged employment, including some international students who possess these qualifications. However, a more profound influence is that it generated unfairness for the vast majority of international students who did not have these qualifications. In this case, these students were evaluated under the same criteria with temporary workers, to whom the LMIA and provincial nominations were more accessible.

The minimum points needed in the later draws to receive invitations in this stage dropped to 481 on March 20, 2015, and the lowest minimum score until November 19, 2016 was 450. The minimum points needed during this period of time remained relatively stable. This trend meant that international students without a job offer supported by an LMIA or a provincial nomination might have had the chance of qualifying for an invitation.

In theory, it is possible for international students to rely on other human capital factors and previous work experience to meet the point requirements. However, after examining the levels of the cut-off points during this stage, this research finds that international students are actually unlikely to receive the minimum points required. As a result, international students will most likely need to work under a temporary post-graduate work permit, so that they can gain Canadian work experience first, and then apply for permanent residency. At this time, the anticipated consequences for international students to immigrate permanently to Canada switched from a one-step process (i.e. from being study permit holders to permanent residents) to a two-step process (i.e. from being study permit holders to work permit holders, and then to permanent residents) (Canadian Center of Policy Alternatives, 2010). Instead of qualifying for permanent residency upon completing their degrees, many more international students now must stay for an additional temporary period of time in order to accumulate enough local work experience. Subsequently, international students in this situation can rely on this work experience to enhance their qualifications for permanent residency. This two-step migration process has become typical 
for international students in Canada who intend to apply for permanent resident status.

\section{The Second Stage}

After the recent modification of the CRS criteria, substantial adjustments that have been made to its points distribution include 50-200 points being awarded to candidates with a valid job offer on LMIA exempt work permits, and 15 or 30 points being awarded to international students who completed their studies in Canada. The minimum amount of CRS points needed to be invited from November 19, 2016 until now has generally followed a declining trend, and the lowest point during this stage for the selection of skilled workers was 413 (see Table 2 below) :

Table 2. The Cut-off Score and Number of Invitations to Apply (ITAs) Issued in Canada's Express Entry Draw (November 19, 2016 - September 6, 2017)

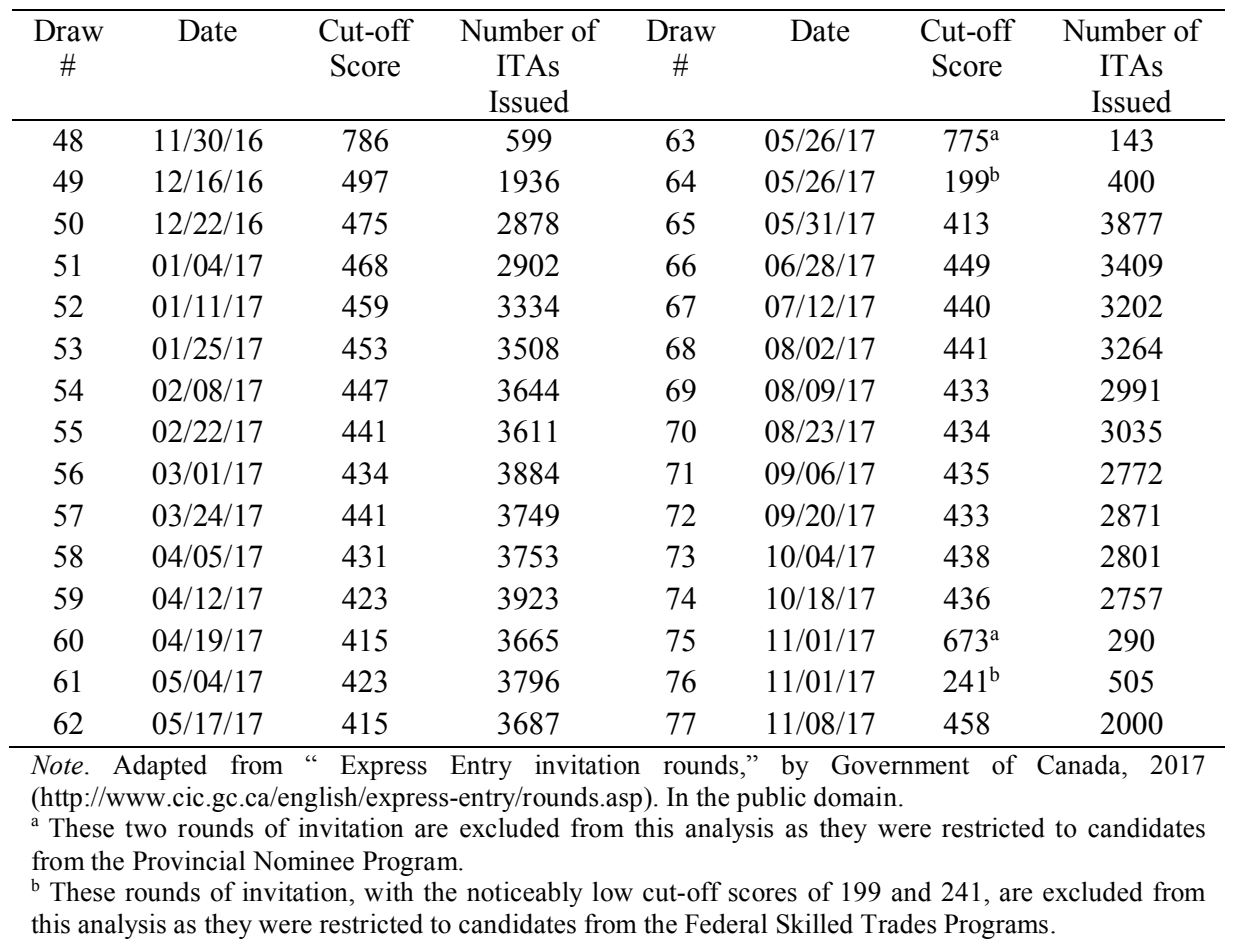


As the CRS points were redistributed in the most recent reform, the qualifications needed in the second stage to receive an invitation have significantly changed from previous stages. This means that the implications of the overall points of candidates should not be interpreted in the same way because the candidates are awarded points based on different criteria. This is to say, the decline in the cut-off points does not necessarily mean it is now easier to receive the invitation. International students' current situation under Express Entry needs to be examined in a more detailed way.

Under the new CRS, awarding 50-200 points to candidates with a valid job offer better acknowledges the value of temporary skilled workers in Canada on an LMIA-exempt work permit. As mentioned before, a vast majority of international students now need to work as skilled temporary foreign workers as their first step of migration, and then seek opportunities to apply for permanent residency as a second step. While working on a temporary basis, international students usually align themselves with highly skilled foreign workers who are unlikely to work in the occupations where an LMIA is needed. According to s. 190 (3) (f) of the Immigration and Refugee Protection Regulations (IRPR), international students are allowed to work under a post-graduate work permit to a maximum of three years after graduation. This regulation enables international students to work for employers without an LMIA during this period of time. Awarding points for job offers on LMIA-exempt work permits weakens the absolute advantages of temporary workers who have a job offer with an LMIA under the CRS, and therefore indirectly improves the situation of international students when they are put in the same pool with temporary workers. An additional side effect of this reform is that international students now have more flexibility in choosing the employers for whom their skills and experiences could be best used. In this sense, this reform also maximizes the utility of international students' labor market skills, as well as meets Canada's economic migration objective.

In terms of the educational credential factor, the modified CRS also awards 15 or 30 points for a degree, diploma, or certificate received in Canada. This change directly places international students in a better position than before. However, these points only account for a small portion of the full 1,200 points. In addition, the opportunity cost of pursuing a longlasting $\mathrm{PhD}$ study is undervalued by this points distribution method. Devoting years of time and effort to pursue a PhD degree after a Bachelor's or a Master's does not bring extra points for candidates, whereas spending 
the same number of years attaining Canadian work experience immediately enhances the candidate's competency in this immigration regime. As such, the current CRS criteria implies that the premium option for international students' transition is to secure arranged employment rather than pursuing further studies that lead them to jobs that are higher in the occupational hierarchy.

\section{DISCUSSION}

This section is devoted to providing a comprehensive evaluation of the effects of the Express Entry system by tracking each reform, as well as objectively assessing its impacts on specific groups of international students as immigration candidates.

\section{Fundamental Advantages of Introducing the Express Entry System}

The most discernible advancement in the Express Entry system lies in its higher efficiency in processing immigration applications. Relative to the previous immigration system, most applicants who are invited to apply for permanent residency under this system now see their applications processed in a timelier fashion. Indeed, CIC states that in $80 \%$ of cases, the time it takes for a final decision to be rendered is less than six months from its receipt of the complete application (CIC, 2016). International students who have received the invitation from CIC can now benefit from the faster processing time under the Express Entry.

Moreover, there is no deadline for international students to complete the Express Entry profile and enter the Express Entry pool. Under Canada's previous immigration policy, applications were processed on a "first come, first serve" basis (Valiani, 2013). Applications received after the cap had been reached would be returned to the applicant; this fact has been proven by historical records. For example, CIC issued a new set of Ministerial Instructions indicating an overall cap of 8,000 applications total, and subcaps of 200 applications each for certain occupations applied for Canadian Experience Class (CEC) in early 2014 (CIC, 2014). It was later discovered that the overall cap was reached in mid-October, 2014, which resulted in the return of almost 8,000 applications submitted then under the CEC, including many applications made by former international students (Choise, 2015). Under the Express Entry system, candidates no longer risk having their applications returned due to the cap having been reached before CIC 
received their applications. This improvement guarantees equal opportunities for all qualified candidates to be evaluated with the same priority.

\section{Impacts on International Students during the First Stage}

During the first stage, international students were generally placed in a disadvantageous position. Due to the extraordinary importance of the 600 points, only a small portion of international students who had obtained a job offer supported by a positive LMIA or a provincial nomination had a good chance of receiving an invitation from CIC to apply for permanent residency, and therefore stood to benefit from the faster processing time under the Express Entry system.

For the vast majority of international students without arranged employment or provincial nominations, however, there were two barriers for obtaining the points required to have a chance of transitioning into permanent residents.

First, the rationale behind the requirement of a positive LMIA was to ensure that qualified Canadians receive priority for an available job opening. A positive LMIA is only issued when there is a recognized need for a foreign worker to fill a job that no qualified Canadian worker is available to do (Alboim \& Cohl, 2012). In contrast to the previous policy, which only required them to have one-year of Canadian work experience in a highly skilled occupation, international students seeking to apply for permanent residency then effectively needed to have their job offers assessed by Employment and Social Development Canada so as to evaluate whether they are displacing Canadians.

Second, international graduates of Canadian schools are eligible for a post-graduation work permit, which allows them to work in Canada temporarily without an LMIA for up to three years. It was problematic to allow international students to work temporarily in Canada without an LMIA, and then require one when they intended to immigrate to Canada. Effectively, what this policy implied is that employers must demonstrate the need to recruit foreign workers to fill in a position that had been legally occupied by an international student for years. This policy requirement appeared to be redundant, and it unnecessarily impeded international students' transition to permanent residents. 


\section{Impacts on International Students during the Second Stage}

After the most recent modification of the Express Entry system, international students' prospects have been slightly improved during the second stage of the invitation process, but permanent residency is still not as accessible as in the era prior to the launch of Express Entry. Typically, a newly graduated international student without sufficient previous work experience could receive around 400 points relying purely on human capital factors under the current CRS system, provided they meet the highest level of language proficiency. This means that educational experience still weighs lightly in this evaluation system and a job offer remains the real decisive factor. Even after attaining one-year of Canadian experience during the waiting period, there is still no guarantee for international students that they will be selected. This situation could worsen, as international students' expectations about better jobs are commonly unmet at the initial stage of their career (Nunes \& Arthur, 2013). International students are no longer able to anticipate the length of their waiting period before being selected.

\section{Impacts on International Students Completing Doctoral Degrees}

Policy changes associated with the introduction of the Express Entry system also negatively impact the ability of current international $\mathrm{PhD}$ students to apply for permanent residency. Through the now defunct $\mathrm{PhD}$ stream under the Federal Skilled Worker Program (FSWP), international students in the midst of completing their doctoral degrees used to be able to automatically qualify for an opportunity to apply for permanent residency after having completed two years of their study. This is no longer the case under the current system. No points are awarded to prospective immigrants for the years of doctoral study in Canada until the degree has been completed. Even then, there is only a 15 -point difference between having a master's degree and having a doctoral degree under the CRS. As such, under the current regime, international $\mathrm{PhD}$ students typically have to wait until they have graduated and have proved to be successful in the Canadian labor market before they are eligible for a permanent residency application.

\section{RECOMMENDATIONS}

The most recent modifications on November 19, 2016 that aimed to balance the situation of international students and temporary workers in the Express Entry pool have seemingly produced positive results. Nevertheless, 
international $\mathrm{PhD}$ students remain the most negatively impacted group among international students. Given that the Express Entry system is a flexible regime and is not quite receptive to a second change for the purpose of overhauling the interests of certain groups of international students, the following alternative recommendations are suggested in order to improve the situation of international $\mathrm{PhD}$ students.

\section{Increase the permitted hours of working off-campus for full-time students}

Express Entry allocates relatively a heavy number of points to Canadian work experience in the section of human capital factors as well as skilled transferability factors. One option to help international $\mathrm{PhD}$ students to meet the immigration requirements faster is to allow them to work more hours while studying in Canada, in order for them to meet the minimum number of required years of work experience before graduation.

To be considered under the Federal Skilled Worker Program (FSWP), applicants must have at least one-year of continuous full-time work experience, or an equal amount of part-time work (1,560 hours total or 30 hours per week). International $\mathrm{PhD}$ students may be able to use their work experience during their study to meet the work experience requirement for FSWP. Since June 2014, full-time international students enrolled at designated institutions in certain programs are permitted to work 20 hours off-campus per week and full-time during scheduled school breaks. It will be helpful if international students are allowed to work more hours during study, so they may be able to gain enough work experience for FSWP faster during their study.

A potential negative result of increasing the permitted work hours is that study permit holders may lead to fraud or misuse of the Canadian study permit for purposes other than study. To avoid this, CIC should also check the enrollment status of international students and make sure they are actively pursuing their studies in Canada. As of June 1, 2014, CIC has already started taking measures to monitor the enrollment status by requiring the designated learning institutions to report the compliance of international students. This effort will help to supervise the activities of international students and mitigate the risk of fraud and misuse of a Canadian study permit. 


\section{Count the work experience while studying toward the immigration work requirements}

An alternative immigration program used by a growing number of international students to migrate is the Canadian Experience Class (CEC), which requires applicants to have 12 months of full-time Canadian work experience at highly skilled occupations (Chatterjee, 2015). To be considered under the CEC, work experience must be gained while on a valid work permit; experience gained while enrolled as a full-time student cannot be counted. Counting the work experience while studying towards the required work experience for immigration will shorten international students' waiting time for permanent residency and remove a crucial barrier for their integration into Canada. In this way, candidates also have the chance to get additional points from Canadian work experience under the CRS, if they have a competent level of language proficiency and the necessary post-secondary credentials.

This recommendation effectively benefits the currently enrolled $\mathrm{PhD}$ students in particular. An international $\mathrm{PhD}$ student usually has access to many job opportunities on campus working as a Teaching Assistant (TA) or Research Assistant (RA). Whether TA/RA experience could be counted towards the immigration requirements has historically caused disputes and a certain degree of confusion in Canada's law enforcement (see Dinani v. Canada, 2014). Candidates who apply under the CEC had seen their applications being rejected because work experience gained while enrolled as a full-time student could not be counted (see Zaraiskaia v. Canada, 2000). An alternative pathway for international students to apply for permanent residency under the FSWP requires their TA/RA work experience to be continuous and paid for at least one year. Given the existing ambiguity in the legal implications of having TA/RA experience, Canada should consider enacting laws that allow students to count work experience gained while enrolled in a full-time program towards the work requirements for immigration. If this recommendation were endorsed, international $\mathrm{PhD}$ students who were left behind by the cancellation of the $\mathrm{PhD}$ stream under the previous FSWP would benefit significantly from the recognition of their TA/RA experience 


\section{CONCLUSIONS}

The original purpose of launching Canada's Express Entry system in 2015 by the then-Conservative government was to speed up the processing of immigration applications to reduce the backlog. However, the effect was actually the opposite. Instead of processing the same number of applications at a faster rate, the government essentially enforced a law that allows fewer international students to qualify under the CRS criteria. As a result, the impression conveyed by the government that international students benefited from having their immigration applications processed faster actually failed to reflect the entire reality of their situation. In fact, the vast majority of international students, who had no prior work experience to count towards points under the CRS, could no longer estimate their waiting period before being invited to submit an actual immigration application.

The most recent policy changes by Canada's Liberal government have, to some extent, improved the chances of receiving permanent residency for international students, but their situations are still not as ideal as prior to Express Entry. International students now need to compete with skilled workers in the Express Entry pool under the CRS criteria, which gives heavier weight to Canadian work experience and lighter weight to Canadian credentials. This system particularly disadvantages international $\mathrm{PhD}$ students because the years of effort they have devoted to pursuing a higher degree results in a missed opportunity to receive points for valuable Canadian work experience towards the immigration requirements.

From the above analyses, this research makes two policy suggestions on the most negatively impacted group of international students, the international $\mathrm{PhD}$ students. Firstly, the government could increase the permitted number of hours for full-time students to work off-campus; secondly, the government could count the work experience while studying towards the required work experience for immigration.

In sum, we can safely draw the conclusion that Canada's Express Entry system had once created severe barriers for international students to transition into permanent residence. With the recent adjustment, international students' situation has been improved while it is still not as satisfactory as in the era prior to Express Entry. Most importantly, international PhD students are still left behind by this Express Entry system. Therefore, additional modifications to the Express Entry system are eagerly awaited. Forward-looking research might explore further reasonable 
changes in this immigration regime, so as to balance the needs of immigration candidates from all categories and to meet Canada's overall immigration objectives.

\section{REFERENCES}

Alboim, N., \& Cohl, K. A. (2012). Shaping the future: Canada's rapidly changing immigration policies $\left(1^{\text {st }}\right.$ ed.). Toronto, ON: Maytree Foundation.

Arthur, N., \& Flynn, S. (2011). Career development influences of international students who pursue permanent immigration to Canada. International Journal for Educational and Vocational Guidance, 11(3), 221-237. doi: 10.1007/s10775-011-9212-5

Bauder, H. (Ed.). (2014). The impact of changes to the CES program on international students (RCIS Working Paper No. 2014/5). Toronto: Ryerson Centre for Immigration \& Settlement, Ryerson University. Retrieved from: http://www.ryerson.ca/content/dam/rcis/documents/ RCIS_WP_GOVision_2014_5.pdf

Bedford, R., \& Spoonley, P. (2014). Competing for talent: Diffusion of an innovation in New Zealand's immigration policy. International Migration Review, 48(3), 891-911. doi:10.1111/imre.12123.

Beine, M., Noël, R., \& Ragot, L. (2014). Determinants of the international mobility of students. Economics of Education Review, 41, 40-54. doi:10.1016/j.econedurev.2014.03.003

Birrell, B., \& Perry, B. (2009). Immigration policy change and the international student industry. People and Place, 17(2), 64-80. Retrieved from http://go.galegroup.com/ps/retrieve.do?tabID=T002\&resultListType=RES ULT_LIST\&searchResultsType $=$ SingleTab\&searchType $=$ AdvancedSearch Form\&currentPosition $=1 \&$ docId $=$ GALE\%7CA206117485\&docType $=$ Arti cle\&sort $=$ RELEVANCE \&contentSegment $=\&$ prodId $=$ AONE \& contentSet $=$ GALE\%7CA206117485\&searchId=R1\&userGroupName=otta77973\&inP $\mathrm{S}=$ true

Canadian Bureau for International Education. (2016). Facts and Figures. Retrieved from http://www.cbie.ca/about-ie/facts-and-figures/

Gates-Gasse, E. (2010). "Two step" immigration: Canada's new immigration system raises troubling issues. Retrieved from: https://www.policyalternatives.ca/publications/monitor/two-stepimmigration

Chatterjee, S. (2015). Skills to build the nation: The ideology of 'Canadian experience' and nationalism in global knowledge regime. Ethnicities, 15(4), 544-567. doi:10.1177/1468796815577702

Choise, S. (2015, March 24) International students in limbo under immigration system changes. The Global and Mail. Retrieved from 
http://www.theglobeandmail.com/news/national/education/internationalstudents-in-limbo-under-immigration-system-changes/article23588415/

Government of Canada. (2017). Express Entry year-end report 2015. Retrieved from http://www.cic.gc.ca/english/resources/reports/ee-year-end-2015.asp

Government of Canada. (2014, April 23). New caps for federal skilled worker and federal skilled trades programs, and Canadian experience class. Retrieved from https://www.canada.ca/en/news/archive/2014/04/new-caps-federalskilled-worker-federal-skilled-trades-programs-canadian-experienceclass.html

Crowley, B. (2014, January 24). In foreign-student gold rush, standards get left behind. The Global and Mail. Retrieved from http://www.theglobeandmail. com/report-on-business/economy/economy-lab/in-foreign-student-goldrush-standards-get-left-behind/article16478016/

Cully, M., Lim, K., Smith, D., \& Levantis, C.. (2011). Do skilled selection policies work? A case study of Australia. Canberra. Department of Immigration and Citizenship Staff Research Paper No. 3.

Dinani v. Canada (Citizenship and Immigration), 2014 F.C. 141, (Can.)

Dobson, J., \& Salt, J. (2009). Pointing the way: Managing UK immigration in difficult times. People and Place, 17(2), 16-29. Retrieved from $\mathrm{http} / /$ go.galegroup.com/ps/i.do?ty $=\mathrm{as} \& \mathrm{v}=2.1 \& \mathrm{u}=\mathrm{otta} 77973 \& \mathrm{it}=$ DIourl\&s $=\mathrm{RELEVANCE} \& \mathrm{p}=\mathrm{AONE} \& \mathrm{qt}=\mathrm{SN} \sim 1039-4788 \sim \mathrm{VO} \sim 17 \sim \sim \mathrm{SP} \sim 16 \sim \sim \mathrm{IU} \sim$ $2 \& \mathrm{~lm}=\mathrm{DA} \sim 120090000 \& \mathrm{sw}=\mathrm{w} \&$ authCount $=1$

Facchini, G., \& Lodigiani, E. (2014). Attracting skilled immigrants: An overview of recent policy developments in advanced countries. National Institute Economic Review, 229(1), R3-R21. doi:10.1177/002795011422900102

Findlay, A. M. (2011). An assessment of supply and demand-side theorizations of international student mobility. International Migration, 49(2), 162-190. doi:10.1111/j.1468-2435.2010.00643.x

Gopal, A. (2016). Visa and immigration trends: A comparative examination of international student mobility in Canada, Australia, the United Kingdom, and the United States. Strategic Enrollment Management Quarterly, 4, 130-141. doi:10.1002/sem3.20091

Gribble, C. (2008). Policy options for managing international student migration: The sending country's perspective. Journal of Higher Education Policy Management, 30 (1), 25-39. doi: 10.1080/13600800701457830

Guellec, D., \& Cervantes, M. (2001). International mobility of highly skilled workers: From statistical analysis to policy analysis. In OECD, International mobility of the highly skilled (pp. 71-98). Paris: OECD.

Hassanein, S. (2014). Increased policy focus on international students credit positive for Canadian universities. Retrieved from University of Toronto, Munk School of Global Affairs website: http://munkschool. 
utoronto.ca/research-articles/increased-policy-focus-on-internationalstudents-credit-positive-for-canadian-universities/

Hawthorne, L. (2010). How valuable is "two-step migration"? Labor market outcomes for international student migrants to Australia. Asian and Pacific Migration Journal, 19(1), 5-36. doi: 10.1177/011719681001900102

Immigration and Refugee Protection Act, S.C. (2001) (Can).

Immigration and Refugee Protection Regulations, SOR/2002-227(Can).

Johnstone, M., \& Lee, E. (2014). Branded: International education and 21 st-century canadian immigration, education policy, and the welfare state. International Social Work, 57(3), 209-221. doi:10.1177/ 0020872813508572

Keung, N. (2015, March 21) Foreign students left behind in new Express Entry immigration program. Toronto Star. Retrieved from https://www.thestar.com/news/immigration/2015/03/21/foreign-studentsleft-behind-in-new-express-entry-immigration-program.html

King, R., \& Raghuram, P. (2013). International student migration: Mapping the field and new research agendas. Population, Space and Place, 19(2), 127137. doi:10.1002/psp. 1746

Lange, T. (2013). Return migration of foreign students and non-resident tuition fees. Journal of Population Economics, 26(2), 703-718. doi:10.1007/s00148012-0436-6.

Lee, J. J., \& Rice, C. (2007). Welcome to America? International student perceptions of discrimination. Higher Education, 53(3), 381-409. doi:10.1007/s10734-005-4508-3

Nunes, S., \& Arthur, N. (2013). International students' experiences of integrating into the workforce. Journal of Employment Counseling, 50 (1), 34-45. doi:10.1002/j.2161-1920.2013.00023.x

Parliament of Canada. (2013). House Government Bill. Retrieved from https://www.parl.ca/LegisInfo/BillDetails.aspx?billId=6258538\&Language $=\mathrm{E}$

Raghuram, P. (2013). Theorising the spaces of student migration. Population, Space and Place, 19(2), 138-154. doi:10.1002/psp.1747

She, Q., \& Wotherspoon, T. (2013). International student mobility and highly skilled migration: a comparative study of Canada, the United States, and the United Kingdom, SpringerPlus, 2(132), 1-14. Retrieved from http://www.springerplus.com/content/2/1/132

Trembaly, K. (2005). Academic mobility and immigration. Journal of Studies in International Education, 9(3), 196-228. doi: 10.1177/1028315305277618.

Valiani, S. (2013). The shifting landscape of contemporary Canadian immigration policy: The rise of temporary migration and employer-driven migration. In Goldring, L. \& Landolt, P. (Eds.), Producing and negotiating non- 
citizenship: Precarious legal status in Canada (pp. 55-70). Toronto: University of Toronto Press.

Zaraiskaia v. Canada (Minister of Citizenship and Immigration), 2000 CanLII16165 (Can. F.C.).

Ziguras, C., \& Law, S. (2006). Recruiting international students as skilled immigrants: the global "skills race" as viewed from Australia and Malaysia. Globalisation, Societies, and Education, 4(1), 59-76. doi: $10.1080 / 14767720600555087$

CHEN WANG is currently completing a $\mathrm{PhD}$ in Law at the University of Ottawa. Her research interests include legal theory and methodology, public international law, immigration and refugee law, and feminist legal studies. Portions of this paper are completed under Professor Naomi Alboim's supervision. I have also benefited from incisive comments by Professor Angela Cameron, Professor Yin Yuan Brandon Chen, and Professor Jamie Chai Yun Liew. Email: CWANG149@uottawa.ca

Manuscript submitted: April 20, 2016

Manuscript revised: January 6, 2017 Accepted for publication: October 27, 2017 